\title{
Larvae of uncommon caridean decapods in the German Bight: species composition, distribution and abundance
}

\author{
I. S. Wehrtmann ${ }^{1} \&$ W. Greve ${ }^{2}$ \\ ${ }^{1}$ Instituto de Zoología "Ernst F. Kilian", Universidad Austral de Chile; Casilla 567, \\ Valdivia, Chile \\ ${ }^{2}$ Biologische Anstalt Helgoland (Zentrale); Notkestr. 31, 22607 Hamburg, Germany
}

\begin{abstract}
Typically, the most abundant group of shrimp larvae in the German Bight is formed by representatives of the family Crangonidae. Larvae of the remaining species have been largely ignored, and only scarce information concerning their ecology is available. Thus, the purpose of the present study was to determine the species composition, distribution and abundance of noncrangonid shrimp larvae in the German Bight in July 1990, after the mildest winter of the century. The material is based upon plankton samples collected at 77 stations, covering the entire German Bight. Eight species were identified, as well as larvae of Palaemonidae and Processa-juveniles. Processa nouveli holthuisi $(53.0 \%)$ and P. modica $(31.3 \%)$ were predominant in the collection. The distribution of the two species was clearly separated: the main concentration of $P$. nouveli holthuisi (peak concentration of 1.94 larvae per $\mathrm{m}^{3}$ ) was confined to the northwest corner of the German Bight, while a majority of $P$. modica larvae (peak concentration of 0.54 larvae per $\mathrm{m}^{3}$ ) occurred at the southwesterly stations. The spatial distribution of Caridion steveni and Eualus occultus around Helgoland indicates the presence of an adult population at the only rocky island in the study area. Other taxa, such as larvae of Palaemonidae and juvenile Pandalina brevirostris were collected exclusively in estuarine habitats. Based upon both the results of the present study and comparable data, we conclude that developmental stages of ten non-crangonid species, as well as representatives of Palaemonidae, can be expected to occur in the plankton of the German Bight. The extremely mild temperatures of the preceding winter may have been, in part, responsible for the relatively high densities of some taxa encountered during our plankton survey. We assume that warm winter temperatures favour the immigration, reproduction and survival of cold-sensitive species.
\end{abstract}

\section{INTRODUCTION}

The brown shrimp, Crangon crangon, is the only shrimp commercially exploited along the Dutch, German and Danish coasts of the North Sea. Most studies on caridean shrimps in the North Sea have been confined to this species because of its abundance in the Wadden Sea and adjacent areas (e.g. Tiews, 1970; Beukema, 1992), its commercial value for the coastal fisheries of the region (e.g. Tiews, 1970, 1983; Boddeke, 1989), and its importance in structuring the soft-bottom shallow-water communities (Reise, 1985; Mattila et al., 1990). There are some studies on other shrimps inhabiting the North Sea. Heerebout (1974) and Adema et al. (1982) published some reports on caridean decapods near the Dutch coast, but the only detailed study on the occurrence and distribution of shrimps in the North Sea was carried out by Wedemeyer (1912).

Our knowledge of the distribution patterns of shrimp larvae in the North Sea is 
mainly based upon the results of the continuous plankton records of the years 1947-1951 (Rees, 1952, 1955) and 1981-1983 (Lindley, 1987). Baan et al. (1972) reported on the presence of decapod larvae in the southern North Sea, and Wehrtmann (1989) provided detailed information on the seasonal occurrence and abundance of caridean shrimp larvae off Helgoland in the German Bight. Although Wehrtmann (1986) described the presence of shrimp larvae in the extended Elbe estuary, the occurrence and distribution of planktonic stages of non-crangonid species in the German Bight are rather unknown.

The aim of the present paper is to describe the distribution and density of developmental stages of shrimps other than Crangonidae in the German Bight during July 1990, after the mildest winter of the century (Beukema, 1992). The results are discussed and compared with the findings of both the continuous plankton records (Rees, 1952, 1955; Lindley, 1987) and the Helgoland data set (Wehrtmann, 1989; Wehrtmann, in prep.).

\section{GERMAN BIGHT}

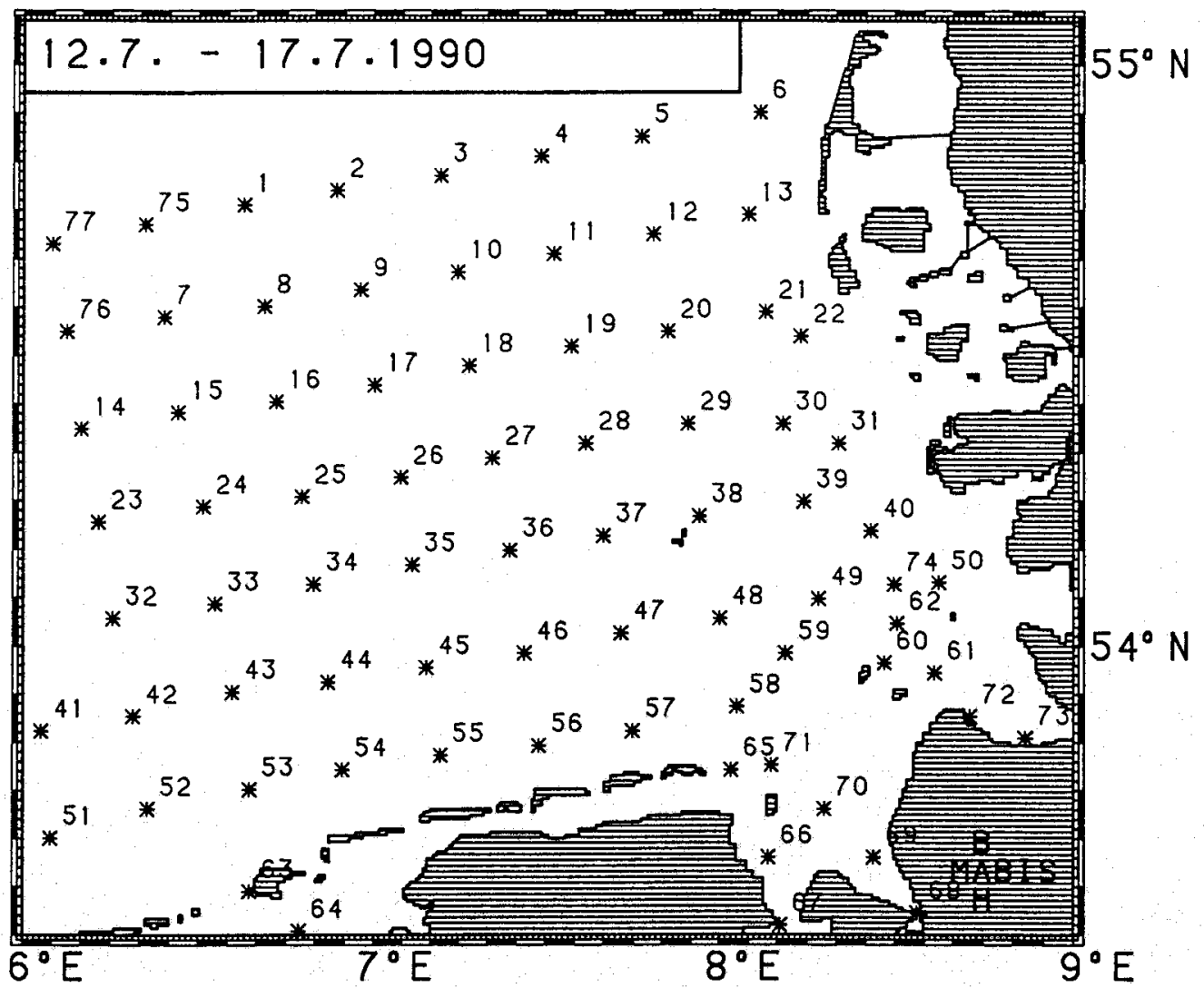

Fig. 1. Location of sampling stations in the German Bight (July, 1990) 


\section{MATERIAL AND METHODS}

The material analysed here is based upon plankton samples collected during the cruise of the RV "Heincke" in July 1990 (12. 7. 1990-17. 7. 1990), which covered the German Bight with 77 stations (Fig. 1). The water depth at the stations ranged from $6 \mathrm{~m}$ (station 50) to $39 \mathrm{~m}$ (station 28), with an average depth of $21.5 \mathrm{~m}$. Oblique tows were taken at each station using a Calcofi-net (mesh size: $500 \mu \mathrm{m}$ ). The net was equipped with a calibrated HydroBios flowmeter to allow subsequent calculation of larval densities which were standardized to individuals per $\mathrm{m}^{-3}$. The mean filtered volume per plankton sample was $151.6 \mathrm{~m}^{3}$, fluctuating between $24 \mathrm{~m}^{3}$ and $367 \mathrm{~m}^{3}$. Temperature and salinity were measured at each station in $5-\mathrm{m}$ intervals from the surface to the bottom. The corresponding results (surface) are presented in Figures 2 and 3. Zooplankton samples were immediately preserved in buffered formaldehyde $(4 \%)$. All noncrangonid shrimp larvae and juveniles were sorted in the laboratory. These were counted and identified to the species level, if possible, according to the keys provided by Williamson $(1957 \mathrm{a}, \mathrm{b})$ and Lebour (1940a). The following descriptions were consulted to prove the identification and to determine the developmental stage of the individual: Athanas nitescens (Sars, 1906;

\section{GERMAN BIGHT}

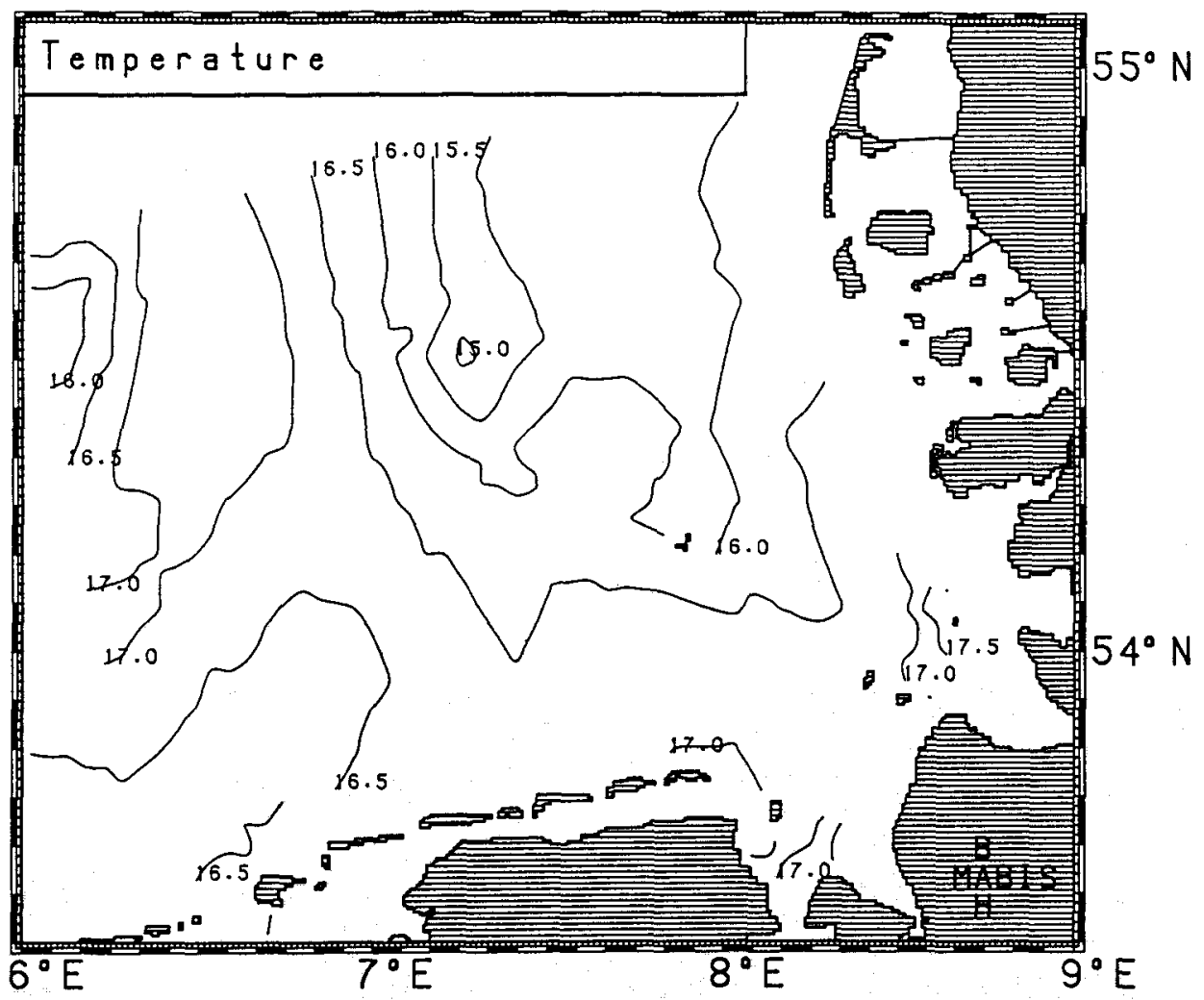

Fig. 2. Surface temperature $\left({ }^{\circ} \mathrm{C}\right)$ at different stations in the German Bight (July, 1990) 


\section{GERMAN BIGHT}

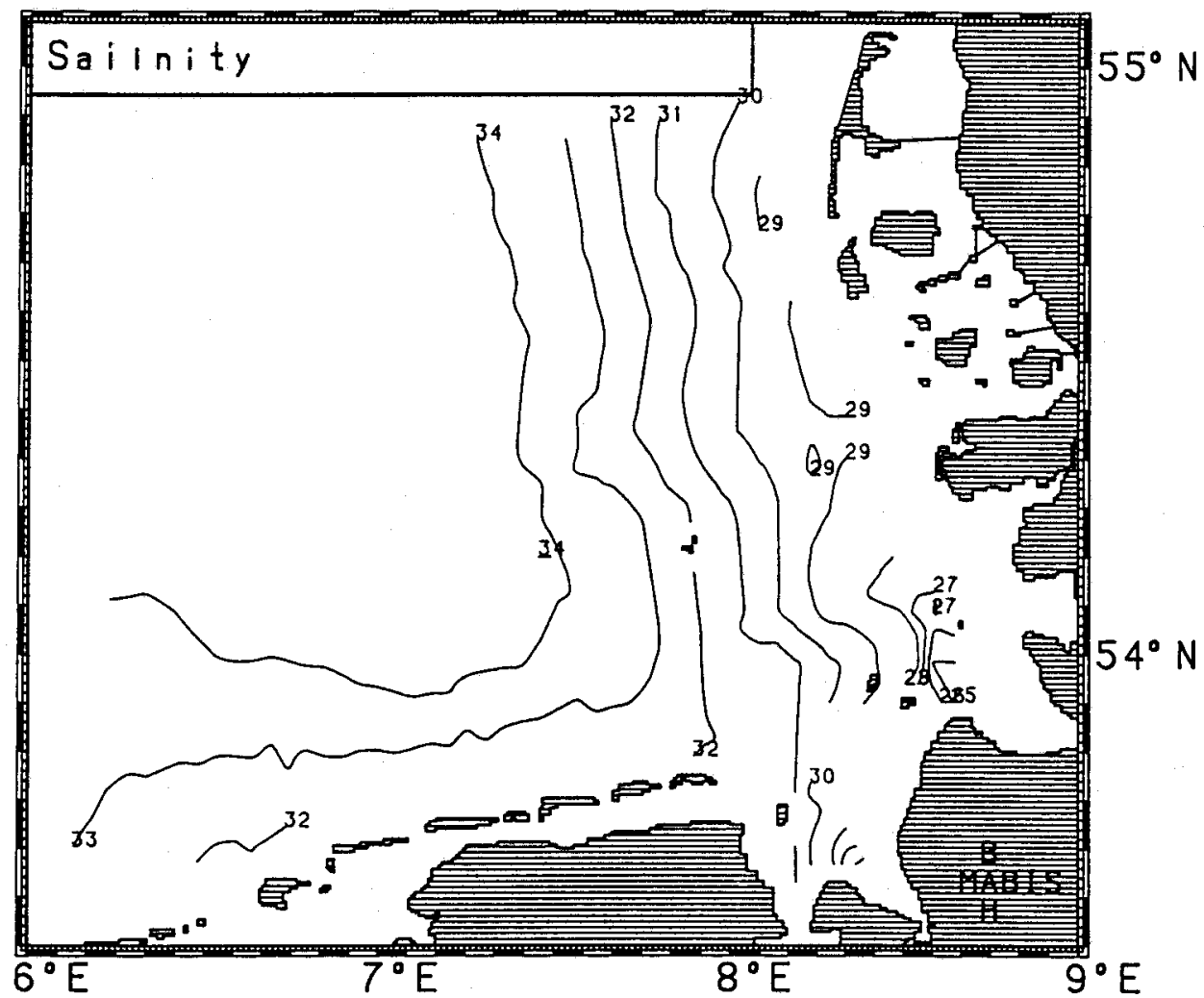

Fig. 3. Surface salinity $(\%)$ at different stations in the German Bight (July, 1990)

Lebour, 1932a), Caridion steveni (Lebour, 1930), Eualus occultus and Eualus pusiolus (Pike \& Williamson, 1961; Lebour, 1940a), Thoralus cranchii (Lebour, 1932b, 1936, 1940a, described as Spirontocaris cranchil), Processa nouveli holthuisi and Processa modica (Williamson \& Rochanaburanon, 1979) and Pandalina brevirostris (Lebour, 1940b; Williamson, 1967).

The discrimination of the diverse communities, as indicated by the decapod larvae assemblages, was determined by cluster analysis techniques (Whittaker \& Fairbanks, 1958), using the programme package Cluster (Reiners \& Greve, 1985). The similarity coefficient was calculated for all stages sampled and discriminated on the basis of a "percentage similarity", thereby standardizing the coefficient.

\section{RESULTS}

\section{General species composition}

From the 3233 individuals (larval and juvenile stages) encountered in the plankton samples, eight species could be identified, as well as undetermined larvae of the family 


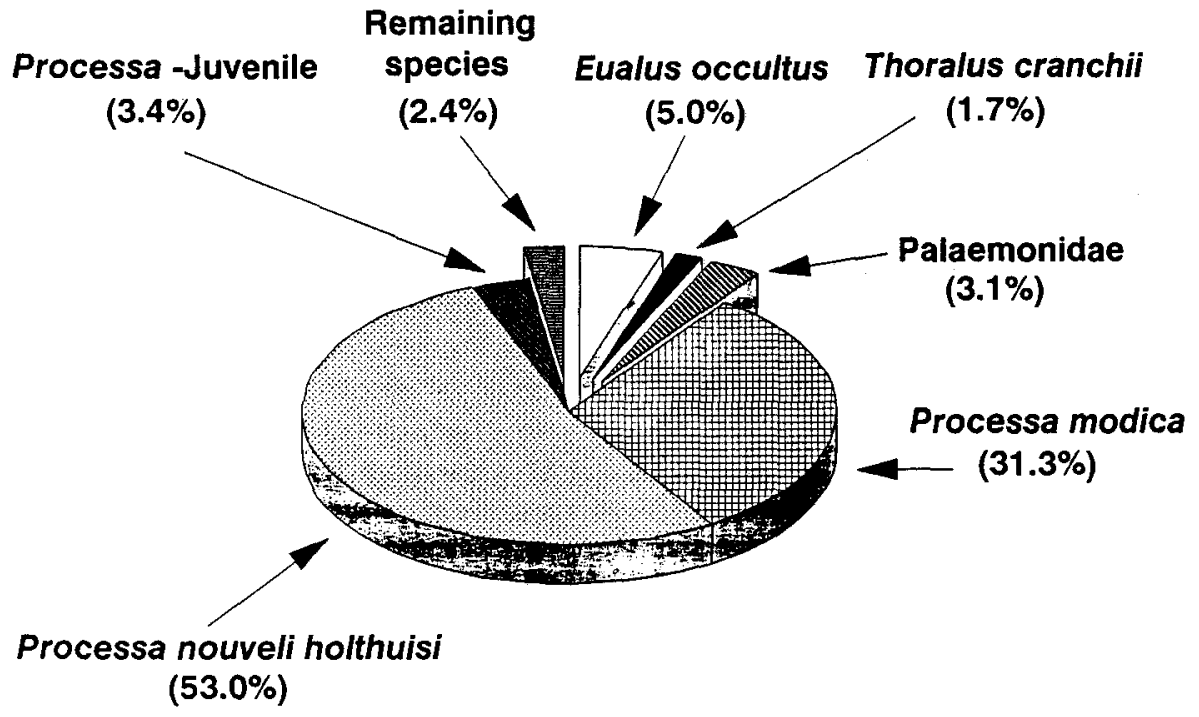

Fig. 4. Percentage of the predominant taxa collected in the German Bight (July, 1990)

Palaemonidae and Processa-juveniles. A minor part of the sorted material $(2.4 \%)$ remained unidentified, mainly due to the deteriorated condition of the preserved individuals.

Developmental stages of Processa nouveli holthuisi and Processa modica were by far the most abundant specimens, comprising $87.7 \%$ (including the Processa-juveniles) of the collected material (Fig. 4). The two species showed also the highest mean densities $\left(0.22\right.$ and 0.13 ind per $\left.\mathrm{m}^{3}\right)$ of the collected species (Table 1). Individuals of Eualus occultus and larvae of Palaemonidae constituted $5.0 \%$ and $3.1 \%$ of the collection,

Table 1. Mean density $(\overrightarrow{\mathrm{x}})$ with standard deviation (S.D.) in individuals per $\mathrm{m}^{3}$ of the different taxa, calculated for the number of stations (n) out of a total of 77 in which they occurred. Maximum concentration (Max.) in individuals per $\mathrm{m}^{3}$ of the different taxa encountered during the plankton survey in the German Bight (July, 1990)

\begin{tabular}{|llllr|}
\hline & $\overline{\mathbf{x}}$ & S.D. & Max. & $\mathrm{n}$ \\
\hline Palaemonidae & 0.05 & 0.08 & 0.18 & 16 \\
Athanas nitescens & 0.01 & - & 0.01 & 1 \\
Caridion steveni & 0.01 & 0 & 0.01 & 3 \\
Eualus occultus & 0.07 & 0.07 & 0.19 & 20 \\
Eualus pusiolus & 0.01 & 0 & 0.01 & 4 \\
Thoralus cranchii & 0.01 & 0.01 & 0.05 & 30 \\
Processa nouveli holthuisi & 0.22 & 0.40 & 1.94 & 41 \\
Processa modica & 0.13 & 0.13 & 0.54 & 52 \\
Processa - juveniles & 0.05 & 0.05 & 0.19 & 13 \\
Pandalina brevirostris - juveniles & 0.01 & 0 & 0.01 & 2 \\
\hline
\end{tabular}


respectively; the specimens of the remaining species (including Thoralus cranchii) comprised only a minor fraction of the material $(4.2 \%)$.

\section{Species distribution and abundance}

\section{Processa nouveli holthuisi}

All larval stages occurred in the samples, stage IV being most numerous (Fig. 5). They were obtained at 41 out of 77 stations (Table 1). The main centre of larval occurrence was the most north-western area of the German Bight (Fig. 6), where a peak of up to 1.94 larvae per $\mathrm{m}^{3}$ was recorded. Lower larval densities were found at stations located west-northwest of Helgoland. The presence of early larval stages was confined to two separated areas, while the advanced stages were more homogeneously distributed (Fig. 7).

\section{Processa modica}

All larval stages were found in the collection, with the exception of newly-hatched individuals (Fig. 8). Larvae were quite frequent ( $68 \%$ of the stations, Table 1) and were particularly abundant in the western part of the study area (Fig. 9). In contrast to $P$. nouveli holthuisi, larvae were almost absent in the north-west corner of the study area.

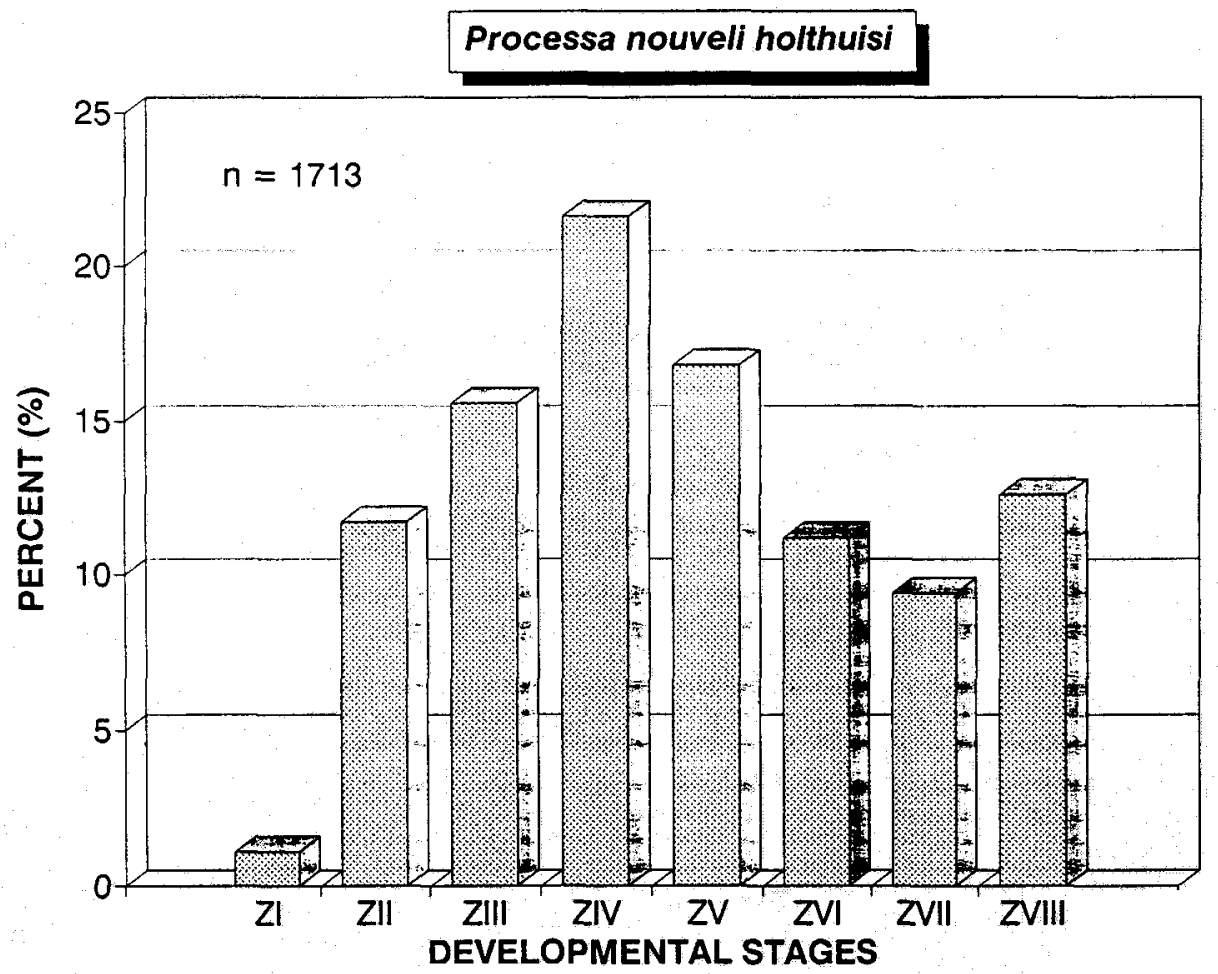

Fig. 5. Processa nouveli holthuisi. Percentage of larval stages collected in the German Bight (July, 1990) 


\section{GERMAN BIGHT}

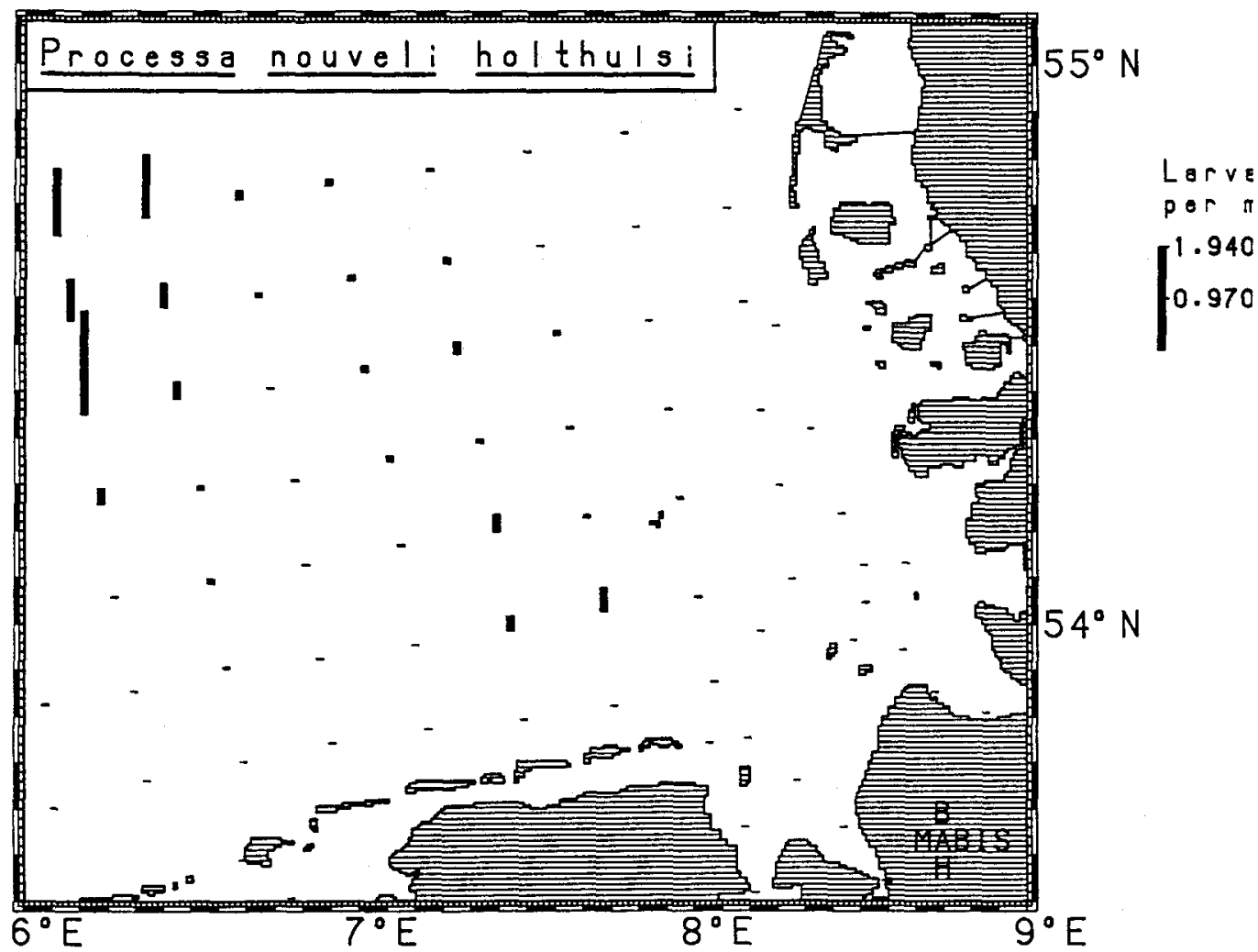

Fig. 6. Processa nouveli holthuisi. Spatial distribution and abundance (larvae per $\mathrm{m}^{3}$ ) of the larval stages collected during the plankton survey in the German Bight (July, 1990)

The results of cluster analysis (Fig. 10) showed the spatial separation of the two species of Processa. The distribution patterns of the different developmental stages were similar to one another (Fig. 11).

\section{Eualus occultus}

Advanced larval stages were predominant, while the first two stages were absent from the material (Fig. 12). Developmental stages occurred at 20 stations, with a distinct centre in the area north-west of Helgoland (Fig. 13). Both mean and maximum densities were considerably lower compared with the two species of Processa (Table 1).

\section{Thoralus cranchii}

The collected material of this species consisted exclusively of advanced larval stages (Fig. 14). Although larvae were never abundant (Table 1), the species was obtained from 30 stations and showed a wide distribution in the study area (Fig. 15). However, larvae were almost absent from all near-coastal stations. Figure 15 demonstrates the spatial separation of larvae representing stage IV-VI in one south-westerly and one north- 


\section{GERMAN BIGHT}

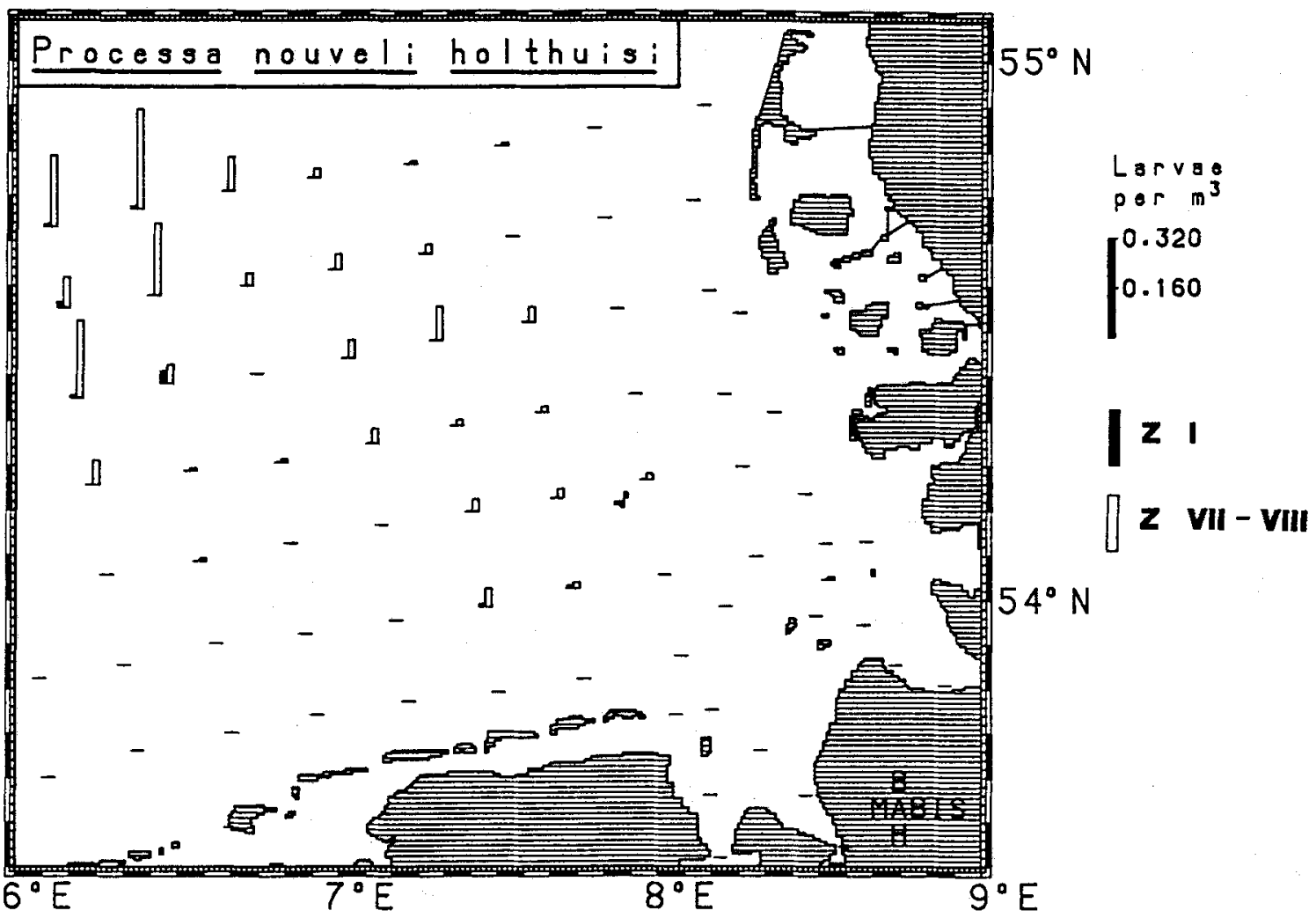

Fig. 7. Processa nouveli holthuisi. Spatial distribution and abundance (larvae per $\mathrm{m}^{3}$ ) of the newlyhatched larvae (Z I) and advanced larval stages ( $Z$ VII + VIII) collected during the plankton survey in the German Bight (July, 1990)

easterly aggregation. These two groups are no longer detectable in the distribution of the advanced stages (Fig. 15).

\section{Remaining species}

With the exception of palaemonid-larvae, which showed a peak density of 0.18 larvae per $\mathrm{m}^{3}$, the remaining species were rare and occurred in low concentrations (Table 1). The spatial distribution of palaemonid larvae is restricted to near-coastal stations located in the Elbe- and Weser-estuaries. Both, Athanas nitescens (2 larvae: stage $\mathrm{V}$ and VIII) and Pandalina brevirostris-juveniles ( 7 specimens) were obtained at two locations (Stations 4, 38 and 58,59, respectively). The five specimens of Eualus pusiolus, representing larvae in stage IV-VI, showed a scattered distribution and were collected at four stations (1,26, 36 and 48). In contrast, the three advanced larvae of Caridion steveni obtained were encountered exclusively in the close vicinity of Helgoland (Stations 28, 29 and 37 ). 


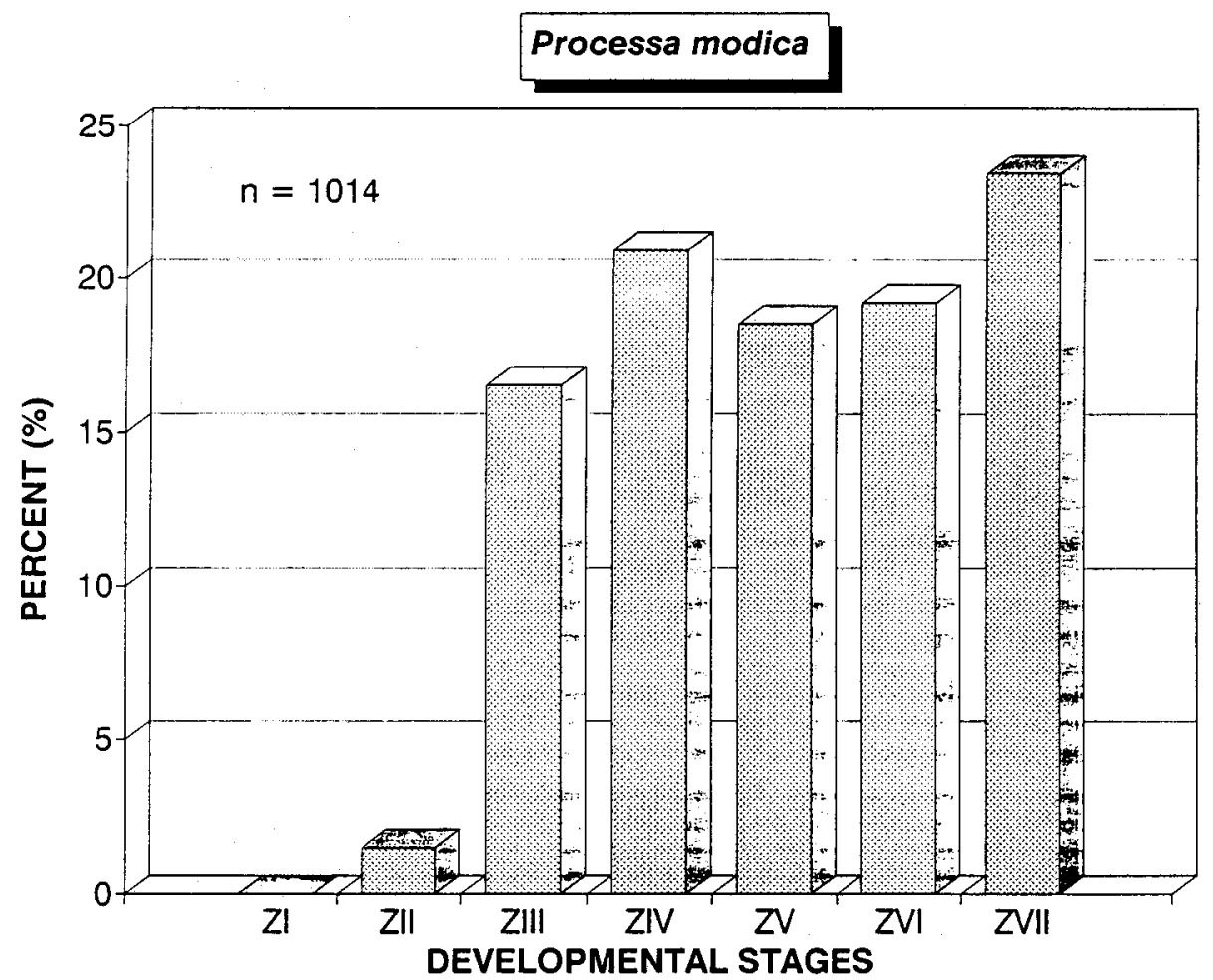

Fig. 8. Processa modica. Percentage of larval stages collected in the German Bight (July, 1990)

\section{Distribution patterns}

Figure 16 presents the distribution and abundance of all non-crangonid shrimp larvae in the German Bight. Developmental stages were generally scarce or absent in near-coastal and estuarine zones, and densities increased in a north-westerly direction within the study area.

Only two groups (juveniles of $P$. brevirostris and Palaemonidae) showed a combination of a positive correlation with temperature and a negative correlation with salinity (Table 2). The separation of these taxa from the remaining species is corroborated by the results of the cluster analysis, although the percent similarity was low.

\section{DISCUSSION}

\section{Species composition}

Developmental stages of eight species, as well as undetermined larvae of Palaemonidae, occurred in our material collected in the German Bight. The species composition is in general agreement with species encountered at Helgoland during an intensive one-year plankton sampling programme (Wehrtmann, 1989) (Table 3). In 


\section{GERMAN BIGHT}

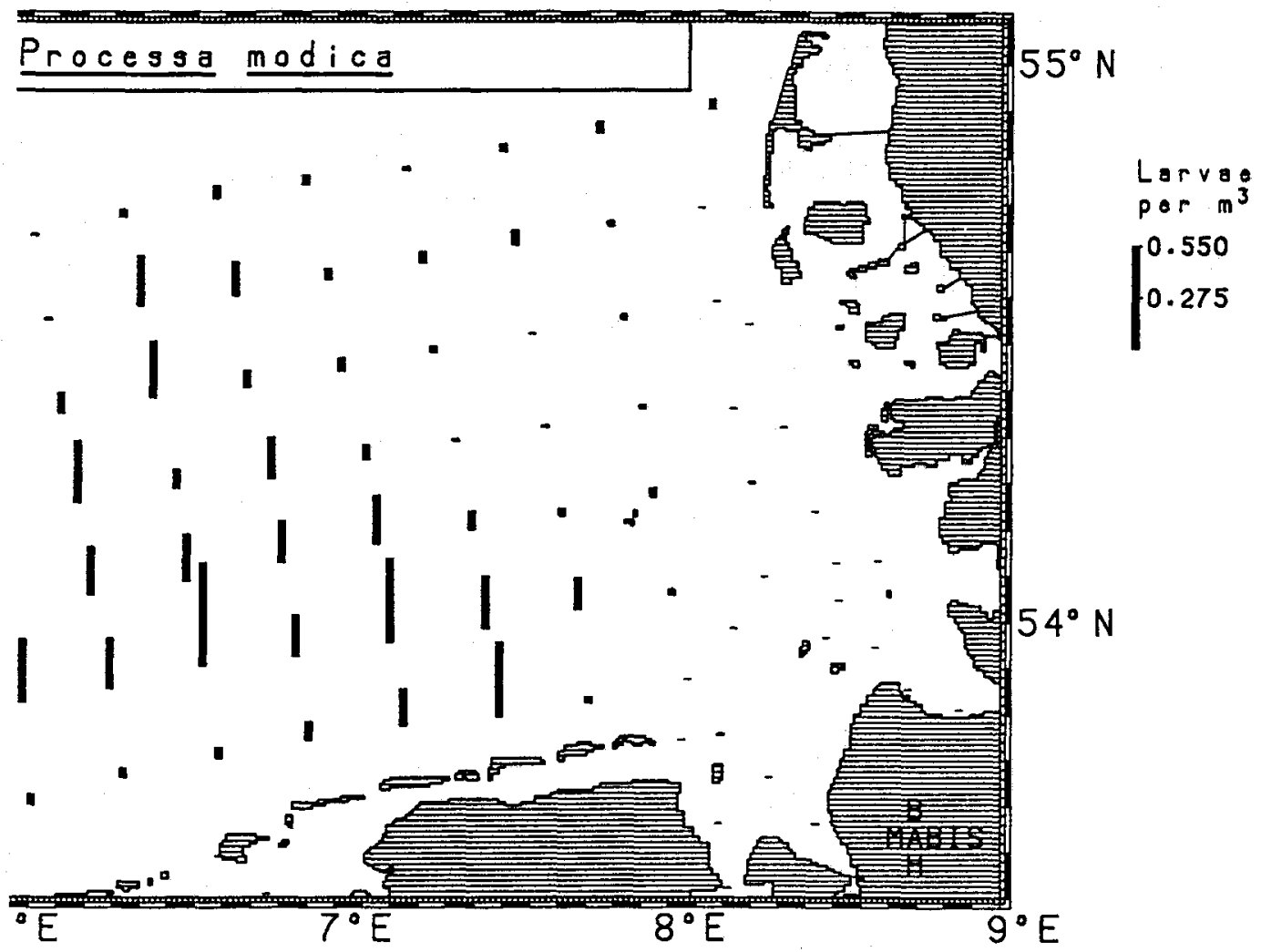

Fig. 9. Processa modica. Spatial distribution and abundance (larvae per $\mathrm{m}^{3}$ ) of the larval stages collected during the plankton survey in the German Bight (July, 1990)

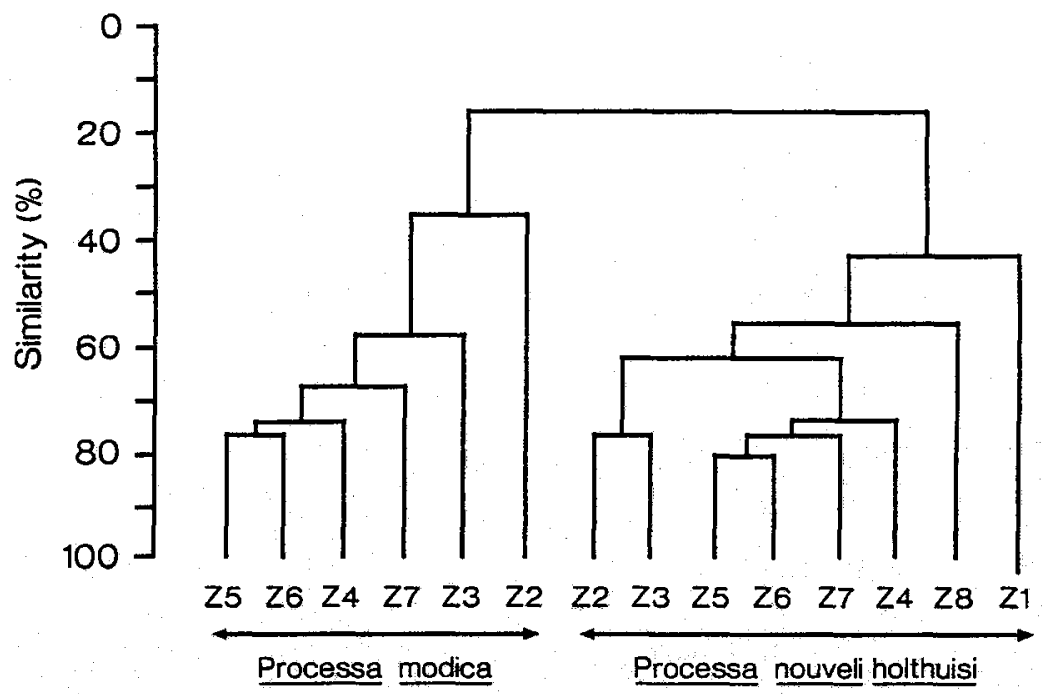

Fig. 10. Similarity dendrogram of $P$. nouveli holthuisi and $P$. modica based upon the distribution of the two species during the plankton survey in the German Bight (July, 1990) 


\section{GERMAN BIGHT}

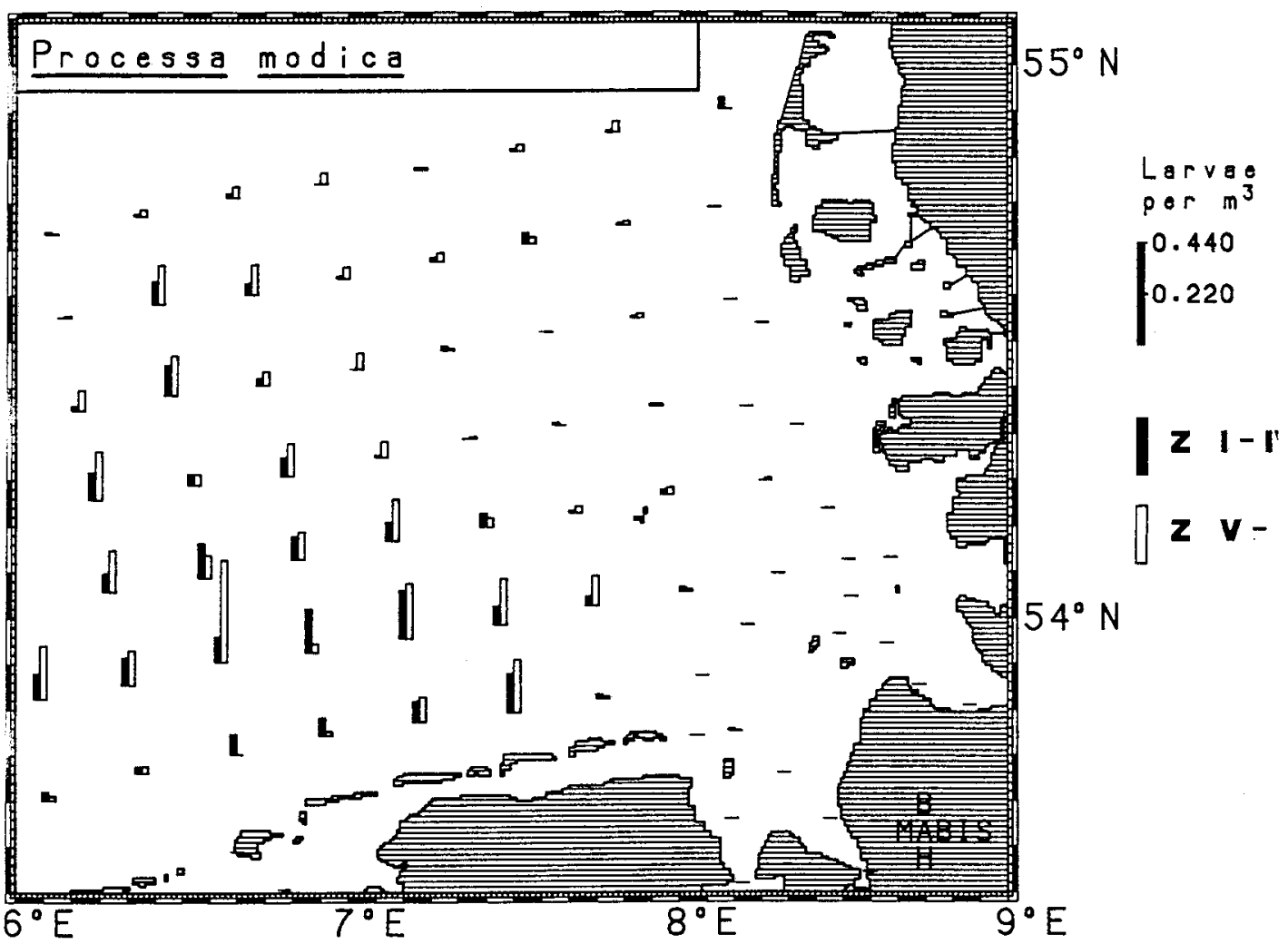

Fig. 11. Processa modica. Spatial distribution and abundance (larvae per $\mathrm{m}^{3}$ ) of early (Z I-Z IV) and advanced larval stages ( $\mathrm{Z}$ V-Z VII) collected during the plankton survey in the German Bight (July, 1990)

contrast to the present study, Palaemonidae, $T$. cranchii and $P$. brevirostris were not found off Helgoland in 1985-1986. However, larvae of $T$. cranchii were collected off Helgoland in 1990 and 1991 (Wehrtmann, in prep.), and adult specimens of $P$. brevirostris are relatively common near Helgoland (Wehrtmann, 1989). Furthermore, the distribution of the Palaemonidae clearly demonstrates that developmental stages of this family are confined to estuarine environments, and therefore they cannot be considered to be a regular component of the shrimp larval fauna at Helgoland. One larva of $P$. montagui was collected in March 1986 at Helgoland (Wehrtmann, 1989). The absence of this species in our collection is an indication that the seasonal occurrence did not coincide with our study period. This interpretation can be corroborated by the seasonality of $P$. montagui larvae in the North Sea (Rees, 1952; Baan et al., 1972; Lindley, 1987) and near Iceland (Astthorsson \& Gislason, 1991). Furthermore, laboratory rearing experiments revealed that larvae can successfully moult and develop at $10^{\circ} \mathrm{C}$ but not at $18^{\circ} \mathrm{C}$ (Pike \& Williamson, 1964). A similar preference for cool temperatures (cf. Rees, 1952; Lindley, 


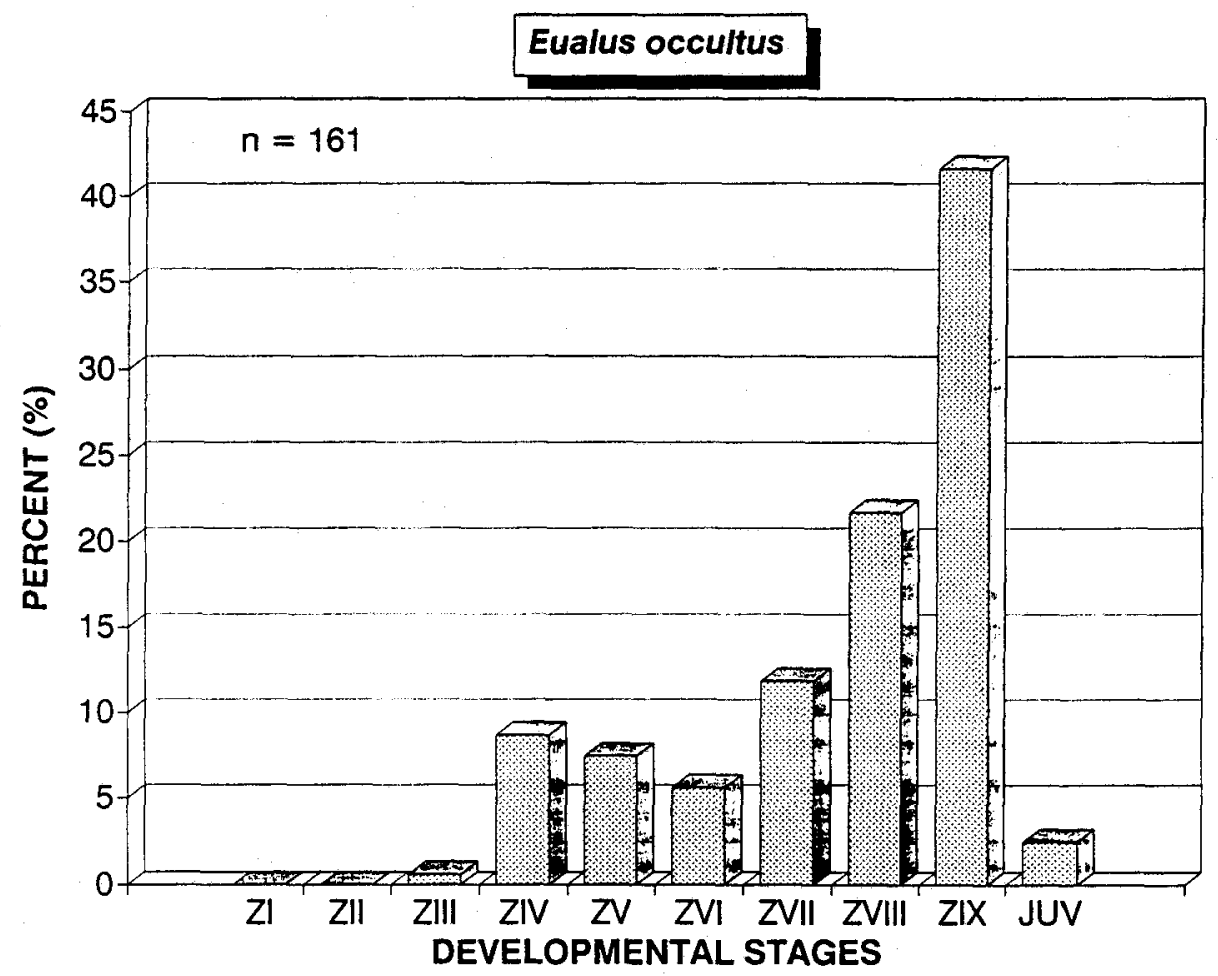

Fig. 12. Eualus occultus. Percentage of larval stages collected in the German Bight (July, 1990)

1987; Wehrtmann, 1989) may explain the absence of Hippolyte varians-larvae in our collection.

Developmental stages of ten non-crangonid species, as well as representatives of Palaemonidae, can be expected to occur in the plankton of the study area. Since the presence of larvae of four members of Crangonidae has been documented by Wehrtmann (1989), larval stages of at least fourteen shrimp species can seasonally form part of the meroplankton community of the German Bight. This relatively high number of shrimp species may be related to the special habitat around Helgoland, which provides an adequate environment for several species usually occurring in the rocky intertidal (see Wehrtmann, 1989).

Our study period was confined to one week in July 1990. Despite the temporal restriction, the number of species encountered of non-crangonid shrimps was relatively high, compared with the results of long-term plankton studies conducted in the southern North Sea (Table 3). The differences in the number of species of both the continuous plankton records (Rees, 1952; Lindley, 1987) and the study conducted by Baan et al. (1972), compared with our results, may be primarily due to different methods. We conclude that even a relatively short sampling period in July provides a fairly reliable picture of the larval species composition in the German Bight.

Our larval survey was conducted subsequent to the mildest winter of the century 


\section{GERMAN BIGHT}

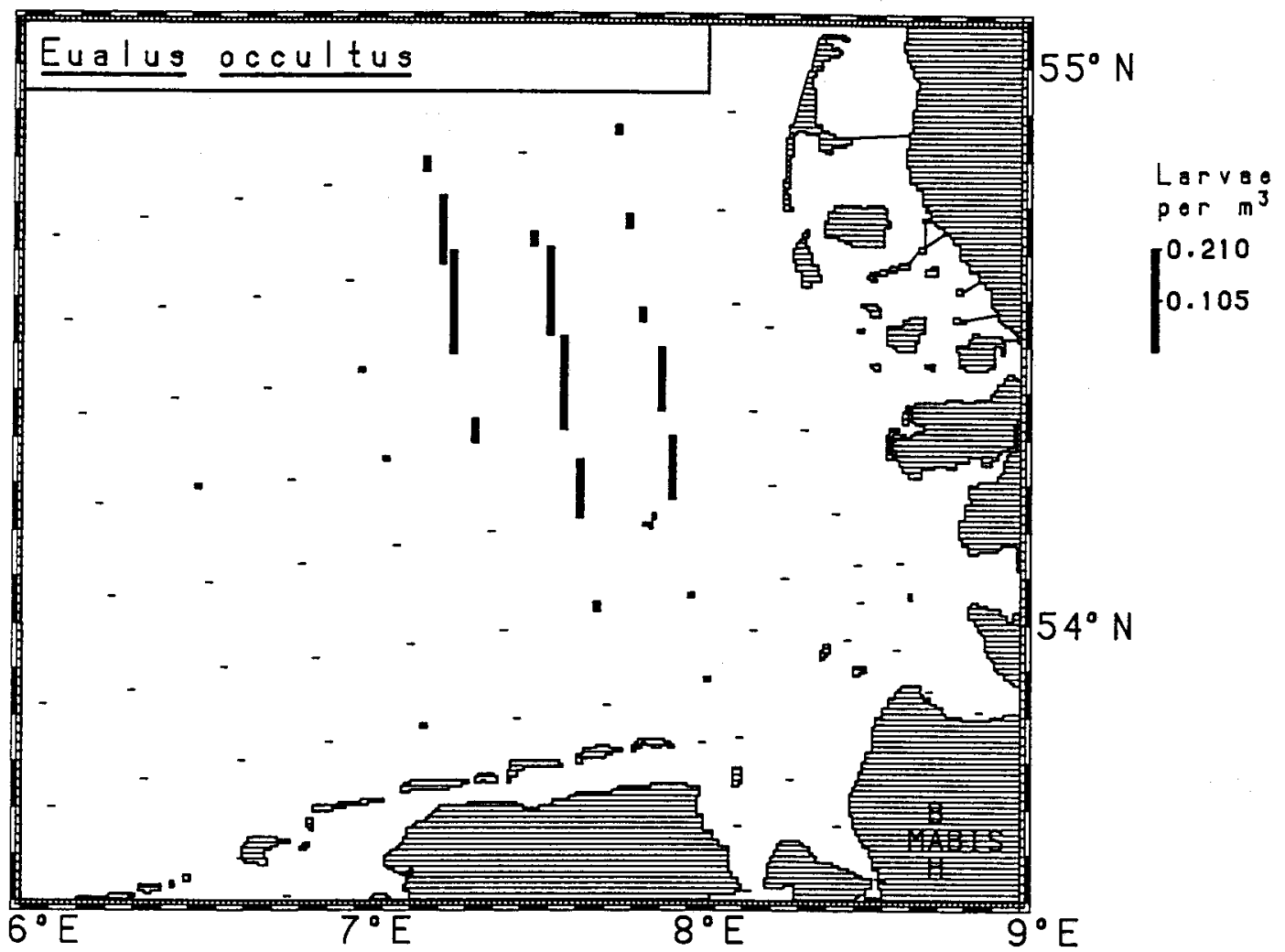

Fig. 13. Eualus occultus. Spatial distribution and abundance (larvae per $\mathrm{m}^{3}$ ) of the larval stages collected during the plankton survey in the German Bight (July, 1990)

(Beukema, 1992). However, because of the lack of comparable data, the effect of preceding winter conditions on the species composition in the study area cannot be evaluated by our results. The prediction that higher winter temperatures cause higher species richness (Beukema, 1990) has to be investigated by interannual comparisons of the outcomes from future larval surveys in the German Bight.

\section{Species abundance}

The mild winter may be, in part, responsible for the relatively high maximum abundances of larvae (Table 1). The recorded larval densities of the two predominant species, $P$. modica and $P$. nouveli holthuisi, were considerably higher than in comparable studies, and demonstrate that Processa spp. larvae can represent a significant seasonal component of the larval decapod community in the German Bight. In contrast, Lindley (1987) mentioned that the larvae of this species were rare (well below 0.08 larvae $\mathrm{m}^{-3}$ ); and after a cold winter (1984/1985), Wehrtmann (1989) reported maximum concen- 


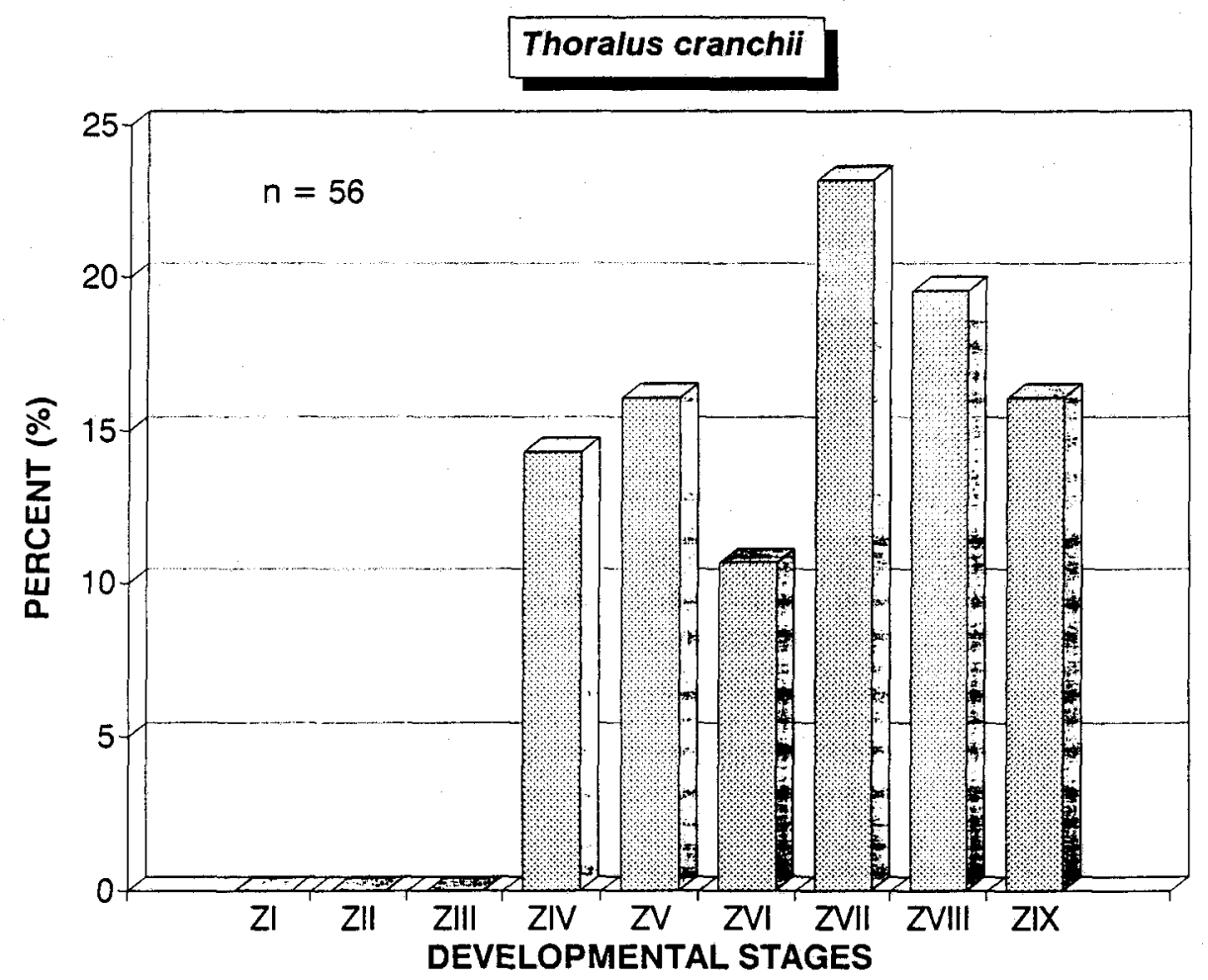

Fig. 14. Thoralus cranchii. Percentage of larval stages collected in the German Bight (July, 1990)

trations of 0.10 and 0.01 larvae $\mathrm{m}^{-3}$ for $P$. modica and $P$. nouveli holthuisi, respectively, at Helgoland. In 1990, a dramatic increase of $P$. nouveli holthuisi larvae was observed (1985: 4 larvae; 1990: 649 larvae) (Wehrtmann, in prep.).

A similar situation has been found for C. steveni at Helgoland: in 1985 only one individual was obtained; in contrast, in 1990 a total of 30 larvae were present in the plankton samples (Wehrtmann, in prep.). The 3 larvae of $C$. steveni collected during our short study period, as well as the above-mentioned data from Helgoland, indicate that warm winter temperatures can exert a significant effect on larval densities of coldsensitive shrimps. The coincidence of high larval concentrations of selected species at Helgoland and in the German Bight lets us assume that 1990 was characterized by an exceptional high larval production and/or survival of these typically Atlantic species. It is hypothesized that the abundances of $P$. nouveli holthuisi and $C$. steveni larvae in the German Bight correlated with the preceding winter temperatures, which has to be substantiated by continuous larval surveys in the area.

\section{Distribution of selected species}

With the exception of the palaemonid larvae, non-crangonıd shrimp larvae were almost completely absent in the estuarine habitats of the German Bight (Fig. 16). 


\section{GERMAN BIGHT}

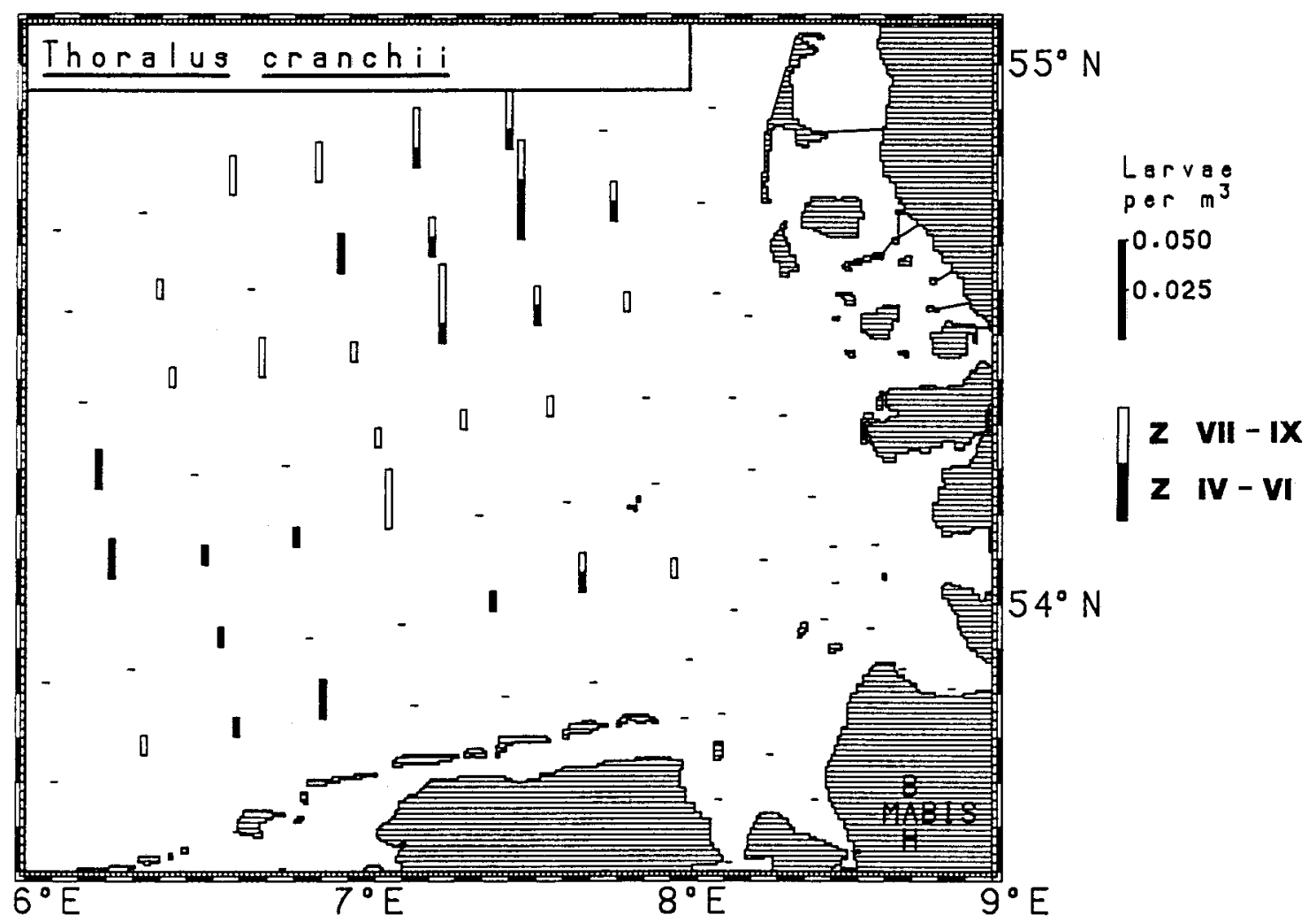

Fig. 15. Thoralus cranchii. Spatial distribution and abundance (larvae per $\mathrm{m}^{3}$ ) of the larval stages (Z IV-Z VI and Z VII- Z IX) collected during the plankton survey in the German Bight (July, 1990)

According to the findings of several larval surveys conducted in different German estuaries (Kühl \& Mann, 1963a, b; 1968; 1969; 1971), the overwhelming majority of shrimp larvae in these areas belongs to $C$. crangon. Also, the results of a larval survey in the extended Elbe estuary clearly show both the scarcity of non-crangonid shrimp larvae and the predominance of Crangon-larvae in estuarine waters (Wehrtmann, 1986). We conclude that the predominance of $C$. crangon-larvae decreases with increasing salinity and, vice versa, that the abundance of non-crangonid larvae increases with increasing salinity. The observed distribution pattern may therefore be interpreted partly as a consequence of the high salinity preference of non-crangonid larvae.

The higher larval densities in the western part of the German Bight (Fig. 16) are due to the spatial distribution of the prevailing species, $P$. nouveli holthuisi and $P$. modica. The distinct larval distribution of the two species may be related to both location of adult populations and advection of planktonic stages. Adults of $P$. modica have been recorded within the North Sea from, among other locations, the Dutch and Belgian coasts (Heerebout, 1974; Al-Adhub \& Williamson, 1975) and the southern North Sea (Williamson \& 


\section{GERMAN BIGHT}

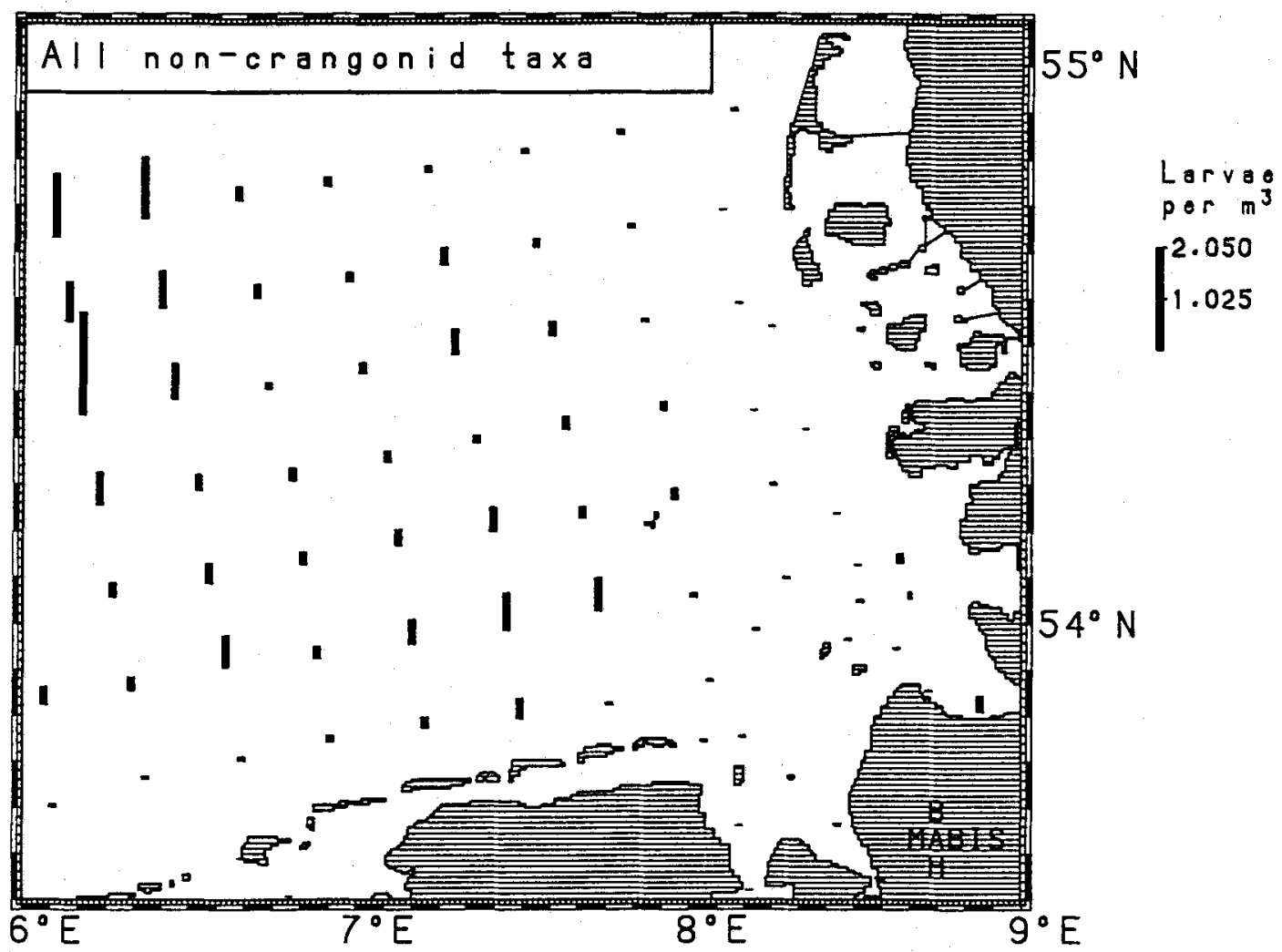

Fig. 16. All non-crangonid taxa. Spatial distribution and abundance (individuals per $\mathrm{m}^{3}$ ) of the developmental stages collected during the plankton survey in the German Bight (July, 1990)

Table 2. Linear correlation coefficients between the different taxa encountered during the plankton survey and environmental variables in the German Bight (July, 1990) $\left(^{*}=p<0.05 ;{ }^{*}=p<0.01\right.$; $\cdots=\mathrm{p}<0.001)$

\begin{tabular}{|lcccc|}
\hline Species & Temperature & Sign.-Niv, & Salinity & Sign.-Niv. \\
\hline Processa modica & +0.111 & & +0.466 & $\ldots$ \\
Processa nouveli holthuisi & -0.014 & & +0.337 & $\ldots$ \\
Caridion steveni & -0.136 & & +0.036 & \\
Athanas nitescens & -0.261 & & +0.043 & \\
Eualus pusiolus & +0.033 & $\ldots$ & +0.133 & $\ldots$ \\
Thoralus cranchii & -0.415 & $\ldots$ & +0.412 & $\ldots$ \\
Eualus occultus & -0.537 & $\ldots$ & +0.164 & \\
Pandalina brevirostris & +0.018 & $\ldots$ & -0.100 & $\ldots$ \\
Palaemonidae & +0.281 & $\ldots$ & -0.581 & $\ldots$ \\
\hline
\end{tabular}


Table 3. Presence of shrimp larvae of different taxa in the southern North Sea based upon the results of various authors

\begin{tabular}{|c|c|c|c|c|c|}
\hline & $\begin{array}{c}\text { Rees } \\
(1952)\end{array}$ & $\begin{array}{l}\text { Baan et al. } \\
\text { (1972) }\end{array}$ & $\begin{array}{l}\text { Lindley } \\
\text { (1987) }\end{array}$ & $\begin{array}{c}\text { Wehrtmann } \\
\text { (1989) }\end{array}$ & $\begin{array}{l}\text { Present } \\
\text { study }\end{array}$ \\
\hline Palaemonidae & & & & & $\mathrm{xxx}$ \\
\hline Athanas nitescens & & & & $\mathrm{xXX}$ & $\mathrm{xxx}$ \\
\hline Caridion steveni & & & & $\mathrm{xxx}$ & $\mathrm{xxx}$ \\
\hline Eualus occultus & & & & $\mathrm{XXX}$ & $\mathrm{XXX}$ \\
\hline Eualus pusiolus & & & & $\mathrm{xxx}$ & $\mathrm{xxx}$ \\
\hline Hippolyte varians & $\mathrm{xXX}$ & $\mathrm{XXX}$ & & $\mathrm{xxx}$ & \\
\hline Thoralus cranchii & & $\mathrm{xxx}$ & & & $\mathrm{xxx}$ \\
\hline Processa nouveli holthuisi & & & & $\mathrm{XXX}$ & $\mathrm{XxX}$ \\
\hline Processa modica & $\mathrm{xxx}$ & $\mathrm{xxx}$ & $\mathrm{xxx}$ & $\mathrm{XXX}$ & $\mathrm{xxx}$ \\
\hline Processa edulis & $\mathrm{xxx}$ & & $\mathrm{xxx}$ & & \\
\hline Pandalina brevirostris & & & $\mathrm{xxx}$ & & $\mathrm{xxx}$ \\
\hline Pandalus montagui & & $\mathrm{XXX}$ & & $\mathrm{XXX}$ & \\
\hline
\end{tabular}

Rochanaburanon, 1979, Türkay, 1986). Therefore, the collected larvae of $P$. modica near the Dutch and German coast may have originated from adult populations located in these areas. In addition, the occurrence of mainly advanced larval stages (Fig. 8 ) indicates that the south-eastern part of the German Bight serves as a settlement area for the first benthic stages of this species.

Adult specimens of $P$. nouveli holthuisi have been recorded mainly from the Irish Sea, off the Cumberland coast, Firth of Clyde and off Northumberland (Smaldon, 1979). However, Smaldon (1979) and Al-Adhub \& Williamson (1975) speculated that the species may also occur in the southern and central North Sea. This speculation has been confirmed by the collection of adult specimens near the islands of Helgoland (Stripp, 1969; Wehrtmann, 1986) and Norderney (Dörjes et al., 1986). Lindley (1987) reported $P$. nouveli holthuisi larvae from the central North Sea and Atlantic areas. Therefore, we assume that the two spatially separated centres of the early larval stages of $P$. nouveli holthuisi (Fig. 7) derive from two different parent populations located in the central North Sea and near Helgoland.

The special habitat of Helgoland (see Janke, 1986) seems to provide adequate conditions for the transition of C. steveni larvae to the benthic phase. Apart from the appearance of individuals in the last larval stage, newly-hatched larvae were found in 1990 for the first time in the plankton at Helgoland (Wehrtmann, in prep.), indicating that the only rocky island in the German Bight maintains a breeding population of C. steveni. However, it should be stressed that, so far, stage-I larvae have only been collected at Helgoland in 1990. The full range of the geographical distribution of $C$. steveni is not yet known (Smaldon, 1979), but the scattered reports of adults (see O'Ceidigh \& McGrath, 1981) and larvae (Lebour, 1930, 1947; Bourdillon-Casanova, 1960; Kurian, 1965; Vives, 1966; Paula, 1987) indicate a distribution primarily restricted to the Atlantic coasts. The proximity of our larval records to Helgoland, as well as the Helgoland plankton data 
(Wehrtmann, 1989, in prep.), confirm Lebour's assumption (1930) that C. steveni must occur at this island.

The area southwest of Helgoland seems to represent a settlement area for $P$. brevirostris. This shallow water species (Holthuis, 1946) has been collected near Helgoland (cf. Wehrtmann, 1989), and juvenile stages are known to occur at the Dutch coast (Heerebout, 1974). The bottom sediments of the stations over which the juveniles were collected (station 58 and 59) are characterized by fine sand and mud (Eisma, 1987). This sediment texture corresponds to the description of the type of settlement substratum selected by juvenile $P$. brevirostris at the Dutch coast (Heerebout, 1974).

The spatial distribution of the larvae of $E$. occultus (Fig. 13) may be related to both a breeding population around Helgoland and the prevailing current system in the area. Adults of this species seem to be rare (Heerebout, 1974) or absent in the southern North Sea (Smaldon, 1979). Furthermore, E. occultus larvae were not listed in the results of the continuous plankton records (Rees, 1952; Lindley, 1987). However, adults (Janke, 1986; Wehrtmann, 1989) and larvae (Wehrtmann, 1989) have been collected at Helgoland. Thus, it may be hypothesized that the larvae encountered during our survey may have hatched at Helgoland and were subsequently advected by the prevailing currents (cf. Wehrtmann, 1986) in northwesterly directions, which would explain the spatial distribution of the larvae in the German Bight.

\section{CONCLUSION}

Despite the short period of sampling, the results of this study demonstrate a relatively high diversity of non-crangonid shrimp larvae in the German Bight which contrasts with the corresponding results of the continuous plankton records (Table 3). However, no comparable data are available to interpret our results in terms of a possible increase/ decrease of both, the number of species and larval densities. Nevertheless, it is remarkable that the presence of approximately $75 \%$ of the recorded species of shrimp larvae in the English Channel (Lebour, 1947), as well as several typically Atlantic species (e.g. C. steveni, E. occultus, Processa spp.) can be now confirmed for the German Bight. Moreover, larval concentrations of some of these species were considerably high (see Table 1). We assume that warm winter temperatures favour the immigration of adults and juveniles, the embryonic development, and the survival of larvae and juveniles of these cold-sensitive species in the German Bight. However, detailed and regular plankton studies are needed to verify the recruitment success of these species during 1990, and, on a more general level, to document possible year-to-year fluctuations in species composition, distribution and density of shrimp larvae in the German Bight and adjacent waters. Such long-term investigations should be of considerable help to evaluate the consequences of climatic variations of oceanographic processes in the North Sea and adjacen 1 waters (see Furnes, 1992) on the shrimp fauna inhabiting the German Bight.

Acknowledgements. This study was partially financed by the Deutsche Forschungsgemeinschaft (DFG; Aktenzeichen $\mathrm{Ha} 138 / 6$ ). During the course of the plankton survey, considerable support was provided by the crew of the RV "Heincke". The main part of the plankton collection was sorted by A V. Vázquez, and we gratefully acknowledge her assistance. Thanks are also due to F. Reiners (Biologische Anstalt Helgoland) for preparing the distribution charts, and to Dr. E. Jaramillc (Instituto de Zoolocía, Universidad Austral de Chile) for his critical comments on an earlier draft of 
the manuscript. 1. Wehrtmann wishes to thank the Biologische Anstalt Helgoland, especially Prof. Dr. W. Gunkel, for providing working facilities and laboratory space; the first author is also grateful to Prof. Dr. G. Hartmann (University of Hamburg) for his ongoing support.

\section{LITERATURE CITED}

Adema, J., Creutzberg, F. \& Noort, G. J. van, 1982. Notes on the occurrence of some poorly known Decapoda (Crustacea) in the southern North Sea. - Zool. Bijdr. 28, 9-32.

Al-Adhub, A. H. Y. \& Williamson, D. I., 1975. Some European Processidae (Crustacea, Decapoda, Caridea). - J. nat. Hist. 9, 693-703.

Astthorsson, O. S. \& Gislason, A., 1991. Seasonal abundance and distribution of Caridea larvae in Isafjord-deep, north-west Iceland. - J. Plankt. Res. 13, 91-102.

Baan, S. M. van der, Holthuis, L. B. \& Schrieken, B., 1972. Decapoda and decapod larvae in the surface plankton from the Southern North Sea near "Texel" lightship. - Zool. Bijdr. 13, 75-97.

Boddeke, R., 1989. Management of the brown shrimp (Crangon crangon) stock in Dutch coastal waters. In: Marine invertebrate fisheries: their assessment and management. Ed. by J. F. Caddy. Wiley, New York, 35-62.

Beukema, J. J., 1990. Expected effects of changes in winter temperatures on benthic animals living in soft sediments in coastal North Sea areas. In: Expected effects of climatic change on marine coastal ecosystems. Ed. by J. J. Beukema, W. J. Wolff \& J. J. W. M. Brouns. Kluwer, Netherlands, (Developments in hydrobiology, 57, 83-92).

Beukema, J. J., 1992. Dynamics of juvenile shrimp Crangon crangon in a tidal-flat nursery of the Wadden Sea after mild and cold winters. - Mar. Ecol. Prog. Ser. 83, 157-165.

Bourdillon-Casanova, L., 1960. Le méroplancton du Golfe de Marseille: les larves de crustacés décapodes. - Recl Trav. Stn mar. Endoume 30, 1-286.

Dörjes, J., Michaelis, H. \& Rhode, B., 1986. Long-term studies of macrozoobenthos in intertidal and shallow subtidal habitats near the island of Norderney (East Frisian coast, Germany). - Hydrobiologia 142, 217-232.

Eisma, D., 1987. The North Sea: an overview. - Phil. Trans. R. Soc. Lond. (B) 316, 461-485.

Furnes, G. K., 1992. Climatic variations of oceanographic processes in the north European seas: a review of the 1970 s and 1980s. - Cont. Shelf Res. 12, 235-256.

Heerebout, G. R., 1974. Distribution and ecology of the Decapoda Natantia of the estuarine region of the rivers Rhine, Meuse and Scheldt. - Neth. J. Sea Res. 8, 73-93.

Holthuis, L. B., 1946. Note on the genus Pandalina (Crustacea Decapoda), with the description of a new species from European waters. - Zool. Meded., Leiden 26, 281-286.

Janke, K., 1986. Die Makrofauna und ihre Verteilung im Nordost-Felswatt von Helgoland. Helgoländer Meeresunters. 40, 1-55.

Kühl, H. \& Mann, H., 1963a. Über das Zooplankton der Unterelbe. - Veröff. Inst. Meeresforsch. Bremerh. 8, 53-59.

Kühl, H. \& Mann, H., 1963b. On the distribution of shrimp larvae (Crangon crangon L.) in the estuary of the Elbe. - Veröff. Inst. Küst.-Binnenfisch. 27, 50-52.

Kühl, H. \& Mann, H., 1968. Über das Zooplankton der unteren Ems. - Veröff. Inst. Meeresforsch. Bremerh. 11, 119-135.

Kühl, H. \& Mann, H., 1969. Über das Zooplankton der Unterweser und Wesermündung. - Veröff. Inst. Meeresforsch. Bremerh. 12, 43-64.

Kühl, H. \& Mann, H., 1971. Über Hydrochemie und Plankton der Eidermündung. - Veröff. Inst. Meeresforsch. Bremerh. 13, 163-181.

Kurian, C. V., 1965. Larvae of decapod Crustacea from the Adriatic Sea. - Acta adriat. 6, 1-108.

Lebour, M. V., 1930. The larval stages of Caridion, with a description of a new species, C. steveni. Proc. zool. Soc. Lond. 1930, 181-194.

Lebour, M. V., 1932a. The larval stages of the Plymouth Caridea. IV. The Alpheidae. - Proc. zool. Soc. Lond. 1932, 463-469.

Lebour, M. V., 1932b. The larvae of the Plymouth Caridea. II. The larval stages of Spirontocaris cranchii (Leach). - Proc. zool. Soc. Lond. 1932, 131-137. 
Lebour, M. V., 1936. Notes on the Plymouth species of Spirontocaris (Crustacea). - Proc. zool. Soc. Lond. 1936, 89-104.

Lebour, M. V., 1940a. The larvae of the British species of Spirontocaris and their relation to Thor (Crustacea, Decapoda). - J. mar. biol. Ass. U. K. 24, 505-514.

Lebour, M. V., 1940b. The larvae of Pandalidae. - J. mar. biol. Ass. U. K. 24, 239-252.

Lebour, M. V., 1947. Notes on the inshore plankton of Plymouth. - J. mar. biol. Ass. U.K. 26, $527-547$.

Lindley, J. A., 1987. Continuous plankton records: the geographical distribution and seasonal cycles of decapod crustacean larvae and pelagic post-larvae in the north-eastern Atlantic Ocean and the North Sea, 1981-3. - J. mar. biol. Ass. U. K. 67, 145-167.

Mattila, J., Olafsson, E. B. \& Johansson, A., 1990. Predation effects of Crangon crangon on benthic infauna on shallow sandy bottoms - an experimental study from southern Sweden. In: Trophic relationships in the marine environment. Ed. by M. Barnes \& R. N. Gibson. Aberdeen Univ. Press, Aberdeen, 503-516.

O'Ceidigh, P. \& McGrath, D., 1981. Marine fauna of Co Wexford. 3. The first record of the adult of Caridion steveni Lebour (Crustacea: Decapoda) from the Irish coast. - Ir. Nat. J. 20, 208.

Paula, J., 1987. Seasonal distribution of Crustacea Decapoda larvae in S. Torpes bay, south-western Portugal. - Investigación pesq. 51 (Supl. 1), 267-275.

Pike, R. B. \& Williamson, D. 1., 1961. The larvae of Spirontocaris and related genera (Decapoda, Hippolytidae). - Crustaceana 2, 187-207.

Pike, R. B. \& Williamson, D. I., 1964. The larvae of some species of Pandalidae. - Crustaceana 6, 265-284.

Rees, C. B., 1952. Continuous plankton records: the decapod larvae in the North Sea, 1947-1949. Hull Bull. mar. Ecol. 3, 157-184.

Rees, C. B., 1955. Continuous plankton records: the decapod larvae in the North Sea, 1950-51. Bull. mar. Ecol. 4, 69-80.

Reiners, F. \& Greve, W., 1985. Arbeitsvorschrift CLUSTER. Biologische Anstalt Helgoland, Hamburg, 1-14 (AVS 5-85).

Reise, K., 1985. Tidal flat ecology. Springer, Berlin, 191 pp.

Sars, G. O., 1906. Postembryonal development of Athanas nitescens Leach. - Arch. Math. Naturv. 27 (10), 1-29.

Smaldon, G., 1979. British shrimps and prawns. Acad. Press, London, $126 \mathrm{pp}$.

Stripp, K., 1969. Die Assoziationen des Benthos in der Helgoländer Bucht. - Veröff. Inst. Meeresforsch. Bremerh. 12, 95-141.

Tiews, K., 1970. Synopsis of biological data on the common shrimp Crangon crangon (L., 1758). FAO Fish. Synop. 91, 1167-1224.

Tiews, K., 1983. Über die Veränderungen im Auftreten von Fischen und Krebsen im Beifang der deutschen Garnelenfischerei während der Jahre 1954-1981. - Arch. FischWiss. 34 (1), 1-156.

Türkay, M., 1986. Sektion Crustaceen. - Cour. Forsch.Inst. Senckenb. 85, 89-96.

Vives, F., 1966. Zooplancton nerítico de las aguas de Castellón (Mediterráneo occidental). Investigación pesq. 30,49-166.

Wedemeyer, H., 1912. Die Carididen der Nordsee. - Wiss. Meeresunters. (Kiel) 15, 107-164.

Wehrtmann, I. S., 1986. Feld- und Laboruntersuchungen über natante Dekapodenlarven in der Deutschen Bucht. Thesis, Univ. Hamburg, 222 pp.

Wehrtmann, I. S., 1989. Seasonal occurrence and abundance of caridean shrimp larvae at Helgoland, German Bight. - Helgoländer Meeresunters. 43, 87-112.

Whittaker, R. H. \& Fairbanks, C. W., 1958. A study of plankton copepod communities in the Columbia Basin, southeastern Washington. - Ecology 39, 46-65.

Williamson, D. I., 1957a. Crustacea Decapoda larvae I. General. - Fich. Ident. Zooplancton 67, 1-7.

Williamson, D. I., 1957b. Crustacea Decapoda larvae V. Caridea, Fam. Hippolytidae. - Fich. Ident. Zooplancton $68,1-5$.

Williamson, D. I., 1967. Crustacea Decapoda larvae IV. Caridea, Fam. Pandalidae and Alpheidae. Fich. Ident. Zooplancton 109, 1-5.

Williamson, D. I. \& Rochanaburanon, T., 1979. A new species of Processidae (Crustacea, Decapoda, Caridea) and the larvae of the north European species. - J. nat. Hist. 13, 11-33. 